\title{
Direct Spectrophotometric determination of Aluminum (III) using 5-Bromo-2-hydroxy-3-methoxybenzaldehyde-P- hydroxybenzoic hydrazone
}

\author{
B.Saritha and T. Sreenivasulu Reddy \\ Department of Chemistry, Sri Krishnadevaraya University, Anantapur 515003 (A.P), India
}

\begin{abstract}
Highly sensitive and selective direct spectrophotometric method is proposed for the determination of aluminium in various real samples. 5-Bromo-2-hydroxy-3-methoxybenzaldehyde-phydroxybenzoic hydrazone reacts with Al(III) forming yellow coloured soluble complex in aqueous dimethyl formamide which has a $\lambda_{\max }$ at $390 \mathrm{~nm}$ in the pH range 3.0-7.0. The system obeyed Beer's law in the range $0.053-0.755 \mu \mathrm{g} \mathrm{mL}-1$ of $\mathrm{Al}(\mathrm{III})$. The molar absorptivity is $2.66 \times 10^{4} \mathrm{~L} \mathrm{mol-1} \mathrm{cm}-1$ and The Sandell's sensitivity is $0.00104 \mu \mathrm{g} / \mathrm{c} \mathrm{m}^{2}$. The standard deviation of the method for ten determinations of $0.42281 \mu \mathrm{g} / \mathrm{ml}$ of Al(III) is 0.0075 . The correlation coefficient $(\gamma)$ of the calibration equation of the experimental data is 0.9999. Studies on effect of diverse ions showed almost all the anions, except $F^{-}$and a majority of the cations do not interfere in more than 50 fold excess. The interference from $\mathrm{Ni}(\mathrm{II}), \mathrm{Fe}(\mathrm{III}), \mathrm{Cu}(\mathrm{II})$ and $\mathrm{Ti}(\mathrm{IV})$ was eliminated by using suitable masking agents. The direct method was applied for the determination of aluminium in silicate minerals, industrial sludges, soil samples plant extracts, hair, tea and water samples.
\end{abstract}

Key words: $\mathrm{Al}$ (III), Direct spectrophotometric determination, 5-BHMBHBH.

\section{Introduction}

The industrial and biological applications of aluminium are quite abundant. Today this cost effective metal is widely available through out and its alloys are widely used for adding strength and utility ${ }^{1}$. Aluminium is used for dialysis dementia ${ }^{2}$. High amounts of aluminium is toxic for human beings ${ }^{3}$. How ever,its micro nutrient role is well recognized. Its applications range from aerospace industry, transportation, building and electrical transmission, packaging and water treatment. Certain aluminium salts serve as an immune response booster to allow the protein in vaccine to achieve sufficient potency as an immune stimulant. The other side of its effects is increased amounts of dietary aluminium reduced skeletal mineralization (osteophenia) resulting in growth retardation. Aluminium can cause neurotoxicity in very high doses which can alter the function of blood brain barrier ${ }^{4}$. Aluminium increases estrogen related gene expression in human breast cancer cells grown in the laboratory 5 . Hence,accurate determination of aluminium in trace quantities in various natural systems is very important. Spectrophotometry is a good trace analysis technique. Recently several spectrophotometric methods ${ }^{6-30}$ based on the use of various organic reagents are reported for the determination of aluminium. Some of these methods are not sensitive, some suffer from interference, some have limited applications, certain methods are used surfactants, some utilize solvent extraction and some are temperature dependent. The potential analytical applications of hydrazone derivatives by Singh et $\mathrm{al}^{31}$.Krishnareddy et $\mathrm{al}^{32}$ recently reported a sensitive method for the determination of aluminium, but it uses a surfactant. We now report a sensitive and reasonably selective direct spectrophotometric method for the determination of aluminium with out use of surfactant and is applied for its determination in a number of naturally occurring complex samples.

\section{Experimental}

The chromogenicreagent,5-bromo-2-hydroxy-3-methoxybenzaldehyde-p-hydroxy benzoic hydrazone was synthesized in the laboratory by condensing 5 - Bromo-2- hydroxy-3methoxybenzaldehydeand p-hydroxybenzoic hydrazone. A 0.01M DMF solution of the reagent is used in the studies.

$0.01 \mathrm{M}$ stock solution of $\mathrm{Al}(\mathrm{III})$ was prepared by dissolving requisite amount of aluminium ammonium sulphate in distilled water and standardized volumetrically ${ }^{33}$. The working solutions were prepared by diluting the stock solutions with distilled water. Buffer solutions of $\mathrm{pH} 4.0$ were prepared by mixing $0.2 \mathrm{M}$ sodium acetate and $0.2 \mathrm{M}$ acetic acid in suitable proportions and the $\mathrm{pH}$ was adjusted by a $\mathrm{pH}$ meter. 
The absorbance and pH measurements were made on a Perkin Elmer (LAMDA 25) UV-Visible spectrophotometer (Model UV-160A) controlled by a computer fitted with $1 \mathrm{~cm}$ path length quartz cells and an ELICO digital pH meter of (Model LI 613) respectively.

\section{Procedure}

To $5 \mathrm{ml}$ of buffer solution ( $\mathrm{pH} 4.0) 0.5 \mathrm{ml}$ of 5 -BНMBHBH $\left(1 \times 10^{-2} \mathrm{M}\right)$ in DMF was taken in each of a set of $10 \mathrm{ml}$ volumetric flasks, variable amounts of $\mathrm{Al}$ (III) were added and diluted to 10 $\mathrm{ml}$ in a volumetric flask with distilled water. The absorbance of these solutions was measured at 390 $\mathrm{nm}$ against reagent blank and plotted against the mount of aluminium. A straight line corresponded to the equation $\mathrm{A} 390=0.98721 \mathrm{C}+0.00119$. ( $\mathrm{C}$ is the amount of aluminium in $\mu \mathrm{g} / \mathrm{ml}$ ).

\section{Results And Discussion}

The absorption spectrum [Al(III) -5-BHMBHBH] complex showed maximum absorbance at $390 \mathrm{~nm}$ where the reagent showed negligible absorbance. The absorbance was found to be maximum and constant in the $\mathrm{pH}$ range 3.0-7.0. Therefore, the analytical studies were carried out at $\mathrm{pH} 4.0$. A 5 fold molar excess of the reagent is sufficient to obtain maximum colour intensity for a given amount of metal ion.

\section{Table 1. Analytical characteristics of [AI(III) -5-BHMBHBH]}

The molar absorptivity Beer's law ranges, detection limit, determination limit shown in the table-1 indicate the high sensitivity of the method. The effect of diverse ions on the absorbance of the experimental solution showed that all the anions tested(except $\mathrm{F}^{-}$) do not interfere in more than 100 fold excess. Fluoride is tolerable upto 45 fold excess. Among the cations $\mathrm{Pb}$ (II), La(III), $\mathrm{Hg}(\mathrm{II}), \mathrm{V}(\mathrm{V})$ and $\mathrm{Th}(\mathrm{IV})$, do not interfere in more than100 fold excess. Y(III), Bi(III), Mo(VI), Zn(II) and $\mathrm{Zr}(\mathrm{IV})$ are tolerable up to 50 fold excess. The tolerance limits of other metal ions are 40 fold of $\mathrm{Cd}(\mathrm{II}), \mathrm{Se}(\mathrm{IV}), 30$ fold of $\mathrm{Au}(\mathrm{III}), \mathrm{Ru}(\mathrm{III})$ and $\mathrm{Mn}(\mathrm{II}), 20$ fold of $\mathrm{Tl}(\mathrm{III}), \mathrm{Ag}(\mathrm{I}), \mathrm{Cr}(\mathrm{VI})$ and $\mathrm{Ce}(\mathrm{IV})$ and 10 fold excess of $\mathrm{W}(\mathrm{VI})$ and $\mathrm{Pd}(\mathrm{II})$. The tolerance limits of $\mathrm{Ni}(\mathrm{II}), \mathrm{Co}(\mathrm{II}), \mathrm{Fe}(\mathrm{III}), \mathrm{Ti}(\mathrm{IV})$ and $\mathrm{Cu}(\mathrm{II})$ which interfere seriously, are made tolerable to more than 100 fold in the presence of EDTA or iodide as masking gents. The results are presented in Table -2 .

\section{Applications}

The direct method was applied for the determination of aluminium in carbonate and silicate minerals, industrial sludges and soil samples. The sample solutions were prepared as per the recommended procedures for silicate minerals 34 , industrial sludges. ${ }^{35}$ Variable aliquots of the sample solutions were treated with suitable amounts of 5-BHMBHBH and c.p.c. (surfactant) under the prescribed conditions and the absorbances were measured at $390 \mathrm{~nm}$. The amounts of aluminium present in these samples were computed from predetermined calibration plots and presented in Table 3, 4 and 5.

The results obtained in the present method with regard to sludges were compared with those obtained by flame atomic absorption spectrophotometric method and presented. The spectrophotometric method was employed for the determination of aluminium in plant extracts, human hair, tea and waste water samples. The solutions of plant, extract ${ }^{36}$, human hair and tea ${ }^{37}$ were prepared according to the recommended procedures and their aluminium content were determined by the proposed. The plant extract samples were also analysed by flame atomic absorption spectrophotometric method and compared with those of present method and $\mathrm{IPE}^{38}$ reported data. The results are presented in Table 6 and 7.

The proposed direct and derivative spectrophotometric methods are simple, sensitive, less tedious, reasonably selective and are applicable for the analysis of complex materials. The present direct method is found to be more sensitive than those proposed by Nemcova et al ${ }^{39}$, Zhong fang et $a l^{40}$., and Sergio et $\mathrm{al}^{41}$.

\section{Determination of Aluminum in Alloys and Steels}

A $0.1 \mathrm{~g}$ of alloy or steel sample containing (3.34-90.5)\% Al was weighed accurately into a $50 \mathrm{ml}$ Erlenmeyer flask following a method recommended by Parker ${ }^{[42]}$. To this added $5 \mathrm{ml}$ each of conc. Hydrochloric and nitric acid and the mixture was heated gently 1-ml of perchloric acid (sp, Gr. 1.70) was added to the solutions and evaporated until strong fuming. The solution was cooled to room temperature. The soluble salts were dissolved in deionized water. The solution was filtered into a 10-ml calibrated flask. The residue (silica and tungstenic acid) was washed with a small volume (5-ml) of hot (1:99) sulfuric acid by water. The 
filtrate and washing were collected in the same calibrated flask. The contents of the flask were neutralized with dilute ammonia solution. The volume was made up to the mark with deionized water.

An aliquot (1-2)-ml of this solution was pipetted into a 10-ml calibrated flask and the $\mathrm{Al}$ content was determined as described in general procedure.The results are shown in table 8.

\section{Determination of Aluminum in Environmental Water Sample}

Each filtered (through a Whatman no. 40 filter paper) environment water sample $(500-\mathrm{mL})$ was evaporated to dryness with a mixture of $1.5-\mathrm{mL} \mathrm{HCl}$ and $5-\mathrm{mL}$ concentrated

$\mathrm{HNO}_{3}$ in a fume cupboard, following a method recommended by Greenberg et al ${ }^{[43]}$. The salts were dissolved in $10 \mathrm{ml}$ of distilled water by heating the contents.The solution was then cooled, neutralized with dilute ammonia solution and transferred into $50 \mathrm{ml}$ volumetric flask. The contents were made up to the mark with distilled water.

$1 \mathrm{ml}$ of the solution was pipetted into $10 \mathrm{ml}$ calibrated flask and the $\mathrm{Al}$ content was determined as described in general procedure. The analysis of various environmental water samples for aluminium is shown in table-9.

\section{Conclusions:}

The present method is a new, simple, sensitive, selective and less expensive method with $\mathrm{Al}(\mathrm{III})$ 5-BHMBHBH complex was developed for the determination of aluminium in some real, soil and environmental water samples. Although many sophisticated techniques such as pulse polarography, HPLC, AAS, ICP-AES, ICP-MS, etc. are available for the determination of aluminium at trace levels in numerous complex materials, factors such as the low cost of the instrument, easy handling, lack of requirement for consumables and almost no maintenance have caused spectrophotometry to remain a popular technique, particularly in laboratories of developing countries with limited budget. The sensitivity in terms of molar absorptivity and precision in terms of relative standard deviation of the present method are very reliable for the determination of aluminium in real samples.

\section{Acknowledgements}

The authors thank the department of Chemistry of S.K.University Anantapur,for providing the necessary facilities. One of authors (B.Saritha) thanks UGC for providing financial assistence under BSRB scheme.

Table 1. Analytical characteristics of [AI(III) - 5-BHMBHBH]

\begin{tabular}{|l|l|}
\hline Parameter & Direct method $\mathbf{3 9 0} \mathbf{~ n m})$ \\
\hline Beer's law range $\left(\mu \mathrm{g} / \mathrm{m} \mathrm{l}^{-1}\right)$ & $0.053-0.755 \mu \mathrm{g} / \mathrm{m} \mathrm{l}$ \\
\hline Molar absorptivity $\left(\mathrm{L} \mathrm{mol}{ }^{-1} \mathrm{~cm}^{-1}\right)$ & $2.66 \times 10^{4} \mathrm{~L} \mathrm{~mol}{ }^{-1} \mathrm{~cm}^{-1}$ \\
\hline Sandell's sensitivity $\left(\mu \mathrm{g} / \mathrm{c} \mathrm{m}^{2}\right)$ & $0.00104 \mu \mathrm{g} / \mathrm{c} \mathrm{m}^{2}$ \\
\hline correlation coefficient $(\mathrm{r})$ & 0.9999 \\
\hline Relative standard deviation $(\%)$ & 1.773 \\
\hline Y- intercept $(\mathrm{b})$ & 0.00119 \\
\hline Detection limit $\left(\mu \mathrm{g} / \mathrm{m} \mathrm{l}^{-1}\right)$ & 0.0076 \\
\hline Determination limit $\left(\mu \mathrm{g} / \mathrm{m} \mathrm{l}^{-1}\right)$ & 0.0232 \\
\hline Composition $($ Metal $:$ Ligand $)$ & $1: 1$ \\
\hline Stability constant $(B)$ & $1.99 \times 10^{6}$ \\
\hline
\end{tabular}

Table -2. Tolerance limit of foreign ions. Amount of Al (III) $=0.431 \mu \mathrm{g} / \mathrm{ml} \quad \mathrm{pH}=4.0$

\begin{tabular}{|c|c|c|c|}
\hline Ion & $\begin{array}{l}\text { Tolerance Limit } \\
(\mu \mathrm{g} / \mathrm{ml})\end{array}$ & Ion & $\begin{array}{cc}\begin{array}{c}\text { Tolerance } \\
(\mu \mathrm{g} / \mathrm{ml})\end{array} & \text { Limit } \\
\end{array}$ \\
\hline Ascorbate & 1925 & $\mathrm{~Pb}(\mathrm{II})$ & 205 \\
\hline EDTA & 990 & La (III) & 140 \\
\hline Iodide & 880 & $\mathrm{Hg}$ (II) & 90 \\
\hline Thiourea & 660 & Th (IV) & 50 \\
\hline Tartrate & 520 & $\mathrm{Y}(\mathrm{III})$ & 45 \\
\hline Phosphate & 360 & Bi (III) & 45 \\
\hline Thiosulphate & 490 & Mo (VI) & 9 \\
\hline Citrate & 480 & $\mathrm{Zr}(\mathrm{IV})$ & 19 \\
\hline Sulphate & 490 & $\mathrm{Cd}(\mathrm{II})$ & 20 \\
\hline Bromide & 400 & $\mathrm{Se}(\mathrm{IV})$ & 20 \\
\hline Thiocyanate & 300 & $\mathrm{Au}$ (III) & 36 \\
\hline Carbonate & 280 & $\mathrm{Ru}$ (III) & 10 \\
\hline Nitrate & 230 & $\mathrm{Zn}$ (II) & 20 \\
\hline
\end{tabular}


Direct Spectrophotometric determination of Aluminum (III) using 5-Bromo-2-hydroxy-3-

\begin{tabular}{|l|l|l|l|}
\hline Chloride & 190 & $\mathrm{Tl}(\mathrm{III})$ & 25 \\
\hline Oxalate & 150 & $\mathrm{Ag}(\mathrm{I})$ & 20 \\
\hline Fluoride & 30 & $\mathrm{Mn}(\mathrm{II})$ & 40 \\
\hline $\mathrm{Fe}(\mathrm{III})$ & $<1,20^{\mathrm{a}}$ & $\mathrm{Cr}(\mathrm{VI})$ & 30 \\
\hline $\mathrm{Cu}(\mathrm{II})$ & $<1,65^{\mathrm{b}}$ & $\mathrm{Ce}(\mathrm{IV})$ & 30 \\
\hline $\mathrm{Ti}(\mathrm{IV})$ & $<1,60^{\mathrm{a}}$ & $\mathrm{U}(\mathrm{VI})$ & 8 \\
\hline $\mathrm{Ni}(\mathrm{II})$ & $<1,79^{\mathrm{a}}$ & $\mathrm{V}(\mathrm{V})$ & 50 \\
\hline $\mathrm{Co}$ (II) & $<1,90^{\mathrm{a}}$ & $\mathrm{W}(\mathrm{VI})$ & 30 \\
\hline & & $\mathrm{Pd}(\mathrm{II})$ & 5 \\
\hline
\end{tabular}

$\mathrm{a}=$ Masked with EDTA

$\mathrm{b}=$ Masked with iodide

Table -3. Determination of Al (III) in carbonate and silicate minerals

\begin{tabular}{|l|l|l|l|}
\hline \multicolumn{2}{|c|}{ Sample } & Aluminium (\%) \\
\cline { 2 - 4 } & $\begin{array}{l}\text { Certified } \\
\text { value( } \boldsymbol{\mu g} / \mathbf{m l})\end{array}$ & Found* & $\begin{array}{l}\text { Relative error } \\
(\%)\end{array}$ \\
\hline Silica brick (NBS 102) & 1.96 & $1.98 \pm 0.006$ & +1.02 \\
\hline Optical glass (NBS 128) & 1.89 & $1.88 \pm 0.007$ & +0.52 \\
\hline Glass frit(NBS-128) & 1.80 & $1.77 \pm 0.006$ & +1.33 \\
\hline
\end{tabular}

$*$ Average of five determinations \pm S.D

Table -4.Determination of Al (III) in Sludge samples

\begin{tabular}{|l|l|l|}
\hline \multirow{2}{*}{ Sludge samples } & \multicolumn{2}{|c|}{ Amount of aluminium $(\mathbf{m g} / \mathbf{g}) *$} \\
\cline { 2 - 3 } & Present method & AAS method \\
\hline $1402-2$ & $30.156 \pm 0.032$ & $30.4328 \pm 0.0026$ \\
\hline $1402-3$ & $35.558 \pm 0.028$ & $35.466 \pm 0.0015$ \\
\hline $1402-4$ & $32.890 \pm 0.016$ & $33.346 \pm 0.002$ \\
\hline
\end{tabular}

* Average of five determinations \pm S.D

Table -5. Determination of Al (III) in soil samples

\begin{tabular}{|l|l|l|l|}
\hline \multicolumn{1}{|c|}{ Sample } & $\begin{array}{l}\text { Composition (\%) } \\
\text { Certified }(\boldsymbol{\mu g} / \mathbf{m l})\end{array}$ & $\begin{array}{c}\text { Composition (\%) } \\
\text { Found*( } \boldsymbol{\mu g} / \mathbf{m l})\end{array}$ & Relcovery (\%) \\
\hline $\begin{array}{l}\text { Singanamala (ground } \\
\text { cultivation soil) }\end{array}$ & - & $20.45 \pm 0.006$ & - \\
\hline $\begin{array}{l}\text { Gooty (Bengal } \\
\text { gram cultivation soil) }\end{array}$ & 20.0 & $41.04 \pm 0.003$ & 101.45 \\
\hline $\begin{array}{l}\text { Bathalapalli(Sunflower } \\
\text { cultivation soil) }\end{array}$ & - & $25.49 \pm 0.009$ & - \\
\hline
\end{tabular}

* Average of five determinations \pm S.D

Table -6.Determination of Al (III) in soil sample

\begin{tabular}{|c|c|c|c|}
\hline \multirow[t]{2}{*}{ Sample } & \multicolumn{2}{|c|}{ Amount of Al(III) $\left(\mu \mathrm{g} / \mathrm{ml}^{-1}\right)$} & \multirow[t]{2}{*}{$\begin{array}{l}\text { IPE reported } \\
\text { range }^{38}\left(\mathrm{mg} \mathrm{g}^{-1}\right)\end{array}$} \\
\hline & Present method* & AAS method* & \\
\hline Grass & $289 \pm 16$ & $286 \pm 10$ & $252-658$ \\
\hline Maize 638 & $138 \pm 9$ & $137 \pm 11$ & $109-237$ \\
\hline Sprouts 599 & $99 \pm 5$ & $101 \pm 4$ & $67-128$ \\
\hline
\end{tabular}

* Average of five determinations

Table -7.Determination of $\mathrm{Al}$ (III) in human hair, tea and waste water

\begin{tabular}{|c|c|c|c|c|c|c|}
\hline \multirow[b]{2}{*}{ Sample } & \multicolumn{6}{|c|}{ Amount of aluminium $\left(\mu \mathrm{g} / \mathrm{ml}^{-1}\right)$} \\
\hline & Added & Found* & $\operatorname{RSD}(\%)$ & Recovery(\%) & $\begin{array}{l}\text { Reference }^{39} \\
\text { method }\end{array}$ & $\begin{array}{l}\text { Relative } \\
\text { error }(\%)\end{array}$ \\
\hline Tea $^{a}$ & $\begin{array}{l}- \\
5.0 \\
\end{array}$ & $\begin{array}{l}210 \\
215.4 \\
\end{array}$ & $\begin{array}{l}1.41 \\
1.10 \\
\end{array}$ & $\begin{array}{l}- \\
100.2 \\
\end{array}$ & $\begin{array}{l}211.5 \\
216.1 \\
\end{array}$ & $\begin{array}{l}+0.71 \\
+0.32 \\
\end{array}$ \\
\hline Human hair & $\overline{5}-\overline{0}$ & $\begin{array}{l}18.8 \\
23.4 \\
\end{array}$ & $\begin{array}{l}0.90 \\
0.91\end{array}$ & $\begin{array}{l}- \\
98.3\end{array}$ & $\begin{array}{l}18.3 \\
23.2 \\
\end{array}$ & $\begin{array}{l}-1.09 \\
-0.86 \\
\end{array}$ \\
\hline Waste water $^{b}$ & $\begin{array}{l}- \\
5.0\end{array}$ & $\begin{array}{l}0.484 \\
5.408\end{array}$ & $\begin{array}{l}0.11 \\
0.14\end{array}$ & $\begin{array}{l}- \\
98.7\end{array}$ & $\begin{array}{l}0.480 \\
5.420\end{array}$ & $\begin{array}{l}-0.83 \\
+0.22\end{array}$ \\
\hline
\end{tabular}

*Average of five determinations

$\mathrm{a}=$ Taj mahal tea sample, $\mathrm{b}=$ Domestic sewage water. 
Table 8Determination of aluminum in certified reference materials.

\begin{tabular}{|l|l|l|l|}
\hline \multirow{2}{*}{$\begin{array}{c}\text { Certified Reference Materials } \\
\text { (Composition,\%) }\end{array}$} & \multicolumn{2}{|c|}{ Aluminium, \% } & Error\% \\
\cline { 2 - 4 } Bureau of Analyzed samples Ltd. No.BAS-20b & & & \\
(Al,90.5;Mg, $1.6 ; \mathrm{Cu}, 4.1 ;$ & 90.50 & 90.41 & 0.09 \\
$\mathrm{Ni}, 1.9 ; \mathrm{Fe}, 0.43 ; \mathrm{Mn}, 0.19 ;$ & & & \\
$\mathrm{Si}, 0.24)$ & & & \\
\hline
\end{tabular}

*Average of five determinations

Table 9 Determination of aluminum in some environmental water samples.

\begin{tabular}{|l|l|l|l|}
\hline \multirow{2}{*}{ sample } & \multicolumn{2}{|l|}{ Aluminium $\boldsymbol{\mu g} / \mathbf{L}^{-1}$} & \multirow{2}{*}{ Recovery $\mathbf{\pm S}(\%)$} \\
\cline { 2 - 4 } & Added & Found $^{\mathbf{a}}$ & \\
\hline \multirow{3}{*}{ Tap water } & 0 & 49.0 & \\
& 25 & 73.8 & $99.7 \pm 0.4$ \\
& 50 & 98.5 & $99.4 \pm 0.5$ \\
\hline \multirow{3}{*}{ Well water } & 0 & 33.0 & $100.5 \pm 0.5$ \\
& 25 & 58.3 & $100.4 \pm 0.4$ \\
\hline
\end{tabular}

\section{References}

[1] Browar H, Importance of aluminum http:// www.firstaluminum.com/articles

[2] Li Z, Lu N, Zhou X and Song Q (2007) Extraction spectrophotometric determination of aluminum in dialysis concentrates with 3,5ditertbutylsalicyl -fluorone and ionic liquid 1-butyl-3-trimethylsilylimidazolium hexafluorophosphate. J Pharma 43(5) : 1609

[3] Venugopal B and Luckey T D (1979) Aluminum in, Metal Toxicity in Mammals 2, Plenum, New York, p 104

[4] Banks,W.A.;Kastin,A.J."Aluminium induced neurotoxicity:alterations in membrane function at the blood-brain barrier"..Neurosci BiobehavRev 13(1);1989; 47.

[5] Mettalloestrogens : an emerging class of inorganic xenoestrogens with potential to add to the oestrogenic burden of the human breast J. Appl. Toxicol;26(3); 2006; 191.

[6] Kamino S, Yamaguchi T, Mori T, Miyamoto M, Kusumi Y and Fujita Y (2005) Spectrophotometric Determination of Aluminum with m-Carboxyphenylfluorone, a Novel Chemical Probe and Its Application. Anal Sci 21(12):1549

[7] Zhou N (2004) Selective Spectrophotometric Determination of Aluminium in the Presence of Beryllium and Lanthanide Cations. Microchimica Acta 146(1) : 73.

[8] Idriss KA, Hashem EY, Aziz MSA and Ahmed HM (2000) Direct spectrophotometric determination of aluminum oxide in Portland cement and cement clinker. An insight into the solution equilibria and analytical aspects of the aluminum-quinizarin system. Analyst 125: 221.

[9] Zareba S and Melke J (2000) Spectrophotometric determination of aluminum in pharmaceutical preparations by azo dyes of 1,2,4triazole series. Pharm Acta Helv 74(4): 361.

[10] Tufan G, Dilek UU, Tevfik G and Ali H (2005) 2,2',3,4-Tetrahydroxy-3'-sulpho-5'-nitroazobenzene for spectrophotometric determination of aluminum in pharmaceutical suspensions and granite. Anal Chimica Acta 545(1) : 107.

[11] Spinola A (1998) Spectrophotometric determination of aluminum in iron ores using solid-phase extraction. J Braz Chem Soc 9(2) : 151

[12] Bahrama M, Madrakianb T, Bozorgzadehb T and A Afkhamib (2007) Micellemediated extraction for simultaneous spectrophotometric determination of aluminum and beryllium using mean centering of ratio spectra. Talanta 72(2): 408

[13] Shokrollahi M Ghaedi, Niband MS and Rajabi HR (2008) Selective and sensitive spectrophotometric method for determination of sub-micro-molar amounts of aluminum ion. J Haza Mate 151(2-3): 642

[14] Niazi A, Zolgharnein J and Davoodabadi MR (2007) Simultaneous determination of aluminum and iron with hematoxylin using spectrophotometric and orthogonal signal correction-partial least squares in plant and water. Ann Chim 97(11-12): 1181

[15] Zheng HL, Xiong MG, Gong YK, Peng DJ and Li LC (2007) Catalytic spectrophotometric determination of trace aluminum with indigo carmine. Spectrochim Acta A Mol Biomol Spectrosc 66(4-5): 1243.

[16] Carpani I, Scavetta E and Tonelli D (2004) Spectrophotometric determination of aluminum and nickel. Ann Chim 94(5-6): 365

[17] He R and Wang J (2000) Novel catalytic spectrophotometric procedure for the determination of trace-level aluminum. Anal Chemica Acta 412(1-2): 241

[18] Pourreza N and Behpour M (1999) Column preconcentration of aluminum using Eriochrome Cyanine R and methyltrioctylammonium chloride adsorbent supported on naphthalene with subsequent spectrophotometric determination.MicrochemicalJ63(2): 250.

[19] Afkhami A and Zarei A R (2004) Simultaneous kinetic determination of beryllium and aluminum by spectrophotometric H-point standard addition method. Anal Sci 20(12):1711.

[20] Rizk M, Zakhari NR, Toubar SS and El-Shabrawy Y (1995) Spectrophotometric determination of aluminum and copper ions using spadns. Microchimica Acta 118 (3-4): 239.

[21] Buratti M, Valla C, Pellegrino O, Rubino FM and Colombi A (2006) Aluminum determination in biological fluids and dialysis concentration via chelation with 8-hydroxy quinolin and solvent extraction fluorimetry. Anal Biochem 353(1): 63.

[22] Ahmed MJ and Hossan J (1995) Spectrophotometric determination of aluminum by morin. Talanta $42: 1135$

[23] Diaz AM, Mariscal JMH, Reguera MIP and Vallvey LFC (1993) Determination of trace of aluminum with chrome azrurol S by solid-phase spectrophotometry. Talanta 40(7): 1059.

[24] Agnihotri NK, Singh HB, Sharma RL and Singh VK (1993) Simultaneous determination of beryllium and aluminum in mixtures using derivative spectrophotometry. Talanta 40(3): 415

[25] Ying-ping H, Ke-mei Y and Hua-shan Z (1999) Spectrophotometric determination of aluminum with 2,3,7-trihydroxy-9-[4-(2,4dihydroxy)phenylazo] phenylfluorone. Wuhan University J Natural Sci 4(2): 219.

[26] Mendez JH, Martinez RC, Cordero B M and Davila LG (1983) Spectrophotometric determination of aluminium with alizarin red S 
Luo M and Bi S (2003) Solid phase extraction spectrophotometric determination of dissolved aluminum in soil extracts and ground waters. J Inorg Biochem 97(1): 173.

[28] Valencia MC, Boudra S and Bosque-Sendra JM (1996) Simultaneous determination of aluminum and beryllium at the subnanogram per millilitre level by solid-phase derivative spectrophotometry. Anal Chimica Acta 327(1) : 73 .

[29] Azhari SJ and Amin SA (2007) Highly sensitive and highly selective spectrophotometric determination of aluminum after collection on a membrane filter using 2,3-dichloro-6-(3-carboxy-2-hydroxy-1-naphthylazo) quinoxaline and zephiramine. Anal Letters 40(15) : 2959.

[30] Ahmed MJ and Nasiruddin M (2007) A simple spectrophotometric method for the determination of cobalt in industrial, environmental, biological and Soil samples using bis(salicylaldehyde)orthophenylenediamine. Chemosphere 67 (10): 2020.

[31] R.B.Singh, P.Jain and R.P.Singh, (1982). Talanta,. 29, 77

[32] S. Satyasree,V. Krishna Reddy and P. Raveendra Reddy, Determination of aluminium (III) in minerals, sludges, soils and plant extracts using 2-hydroxy-3- methoxy benz aldehyde- p-hydroxybenzoic hydrazone, ijsrp 12(2),2012.

[33] A.I. Vogel 'A Text book of Quantitative Analysis' 4th edn, Longmans, London, 1978, 389.

[34] N.L.Benerjee and B.C. Sinha,Extraction spectrophotometric method for determination of aluminium in silicates; Talanta; 37(10);1990; 1017.

[35] Environmental protection Agency, USA, Method, 3050B 1996.

[36] O.C Bataglia, A.M.C.Furlani, J.P.E.Teixeira, P.R.Furlani, J.R.Gallo, Technical Bulletin No.78, 1983, 9.

[37] Ronghuan $\mathrm{He}$ and Jianhuawang, Novelcatalytic spectrophotometricprocedure for the determination of trace- level aluminium;Analytica Chimica Acta, 2000, 412, 241.

[38] Annual Report, International plant-Analytical Exchange (IPE) Wageningen Agricultural University, The Netherlands, 1997.

[39] I. Nemcova, B. Evtimova, and I. Hrachovska, Spectrophotometric Determination of Aluminium (III) and Fluoride ions with Bromopyrogallol Red in the presence of Cationic SurfactantsSeptonex,C.R.Acade.Bulg.Sci. 43(2), 45,1990.

[40] Liu Zhongfang, Liu Shaopu and Wang Xuechao ,Spectrophotometric determination of Aluminium in Copper Alloys with Carboxyazo I ,Chemistry department,SouthWest China Teachers University ;10(4), 1990, 9.

[41] SergioL.C. Ferreira Neide.O.Leite,AlailsonF.Dantas etal., Spectrophotometric and derivative spectrophotometric determination of aluminium with Hydroxynaphthol Blue, Talanta, 41 (10), 1994,1631.

[42] Parker GA (1983) Analytical Chemistry of Molybdenum, Springer Verlag Berlin.

[43] Greenberg AE, Clesceri LS and Trussel RR (edg) (1992) Standared Methods for the Estimation of water and Waste water, 18th ed., American Public Health Association, Washington DC. P 3.

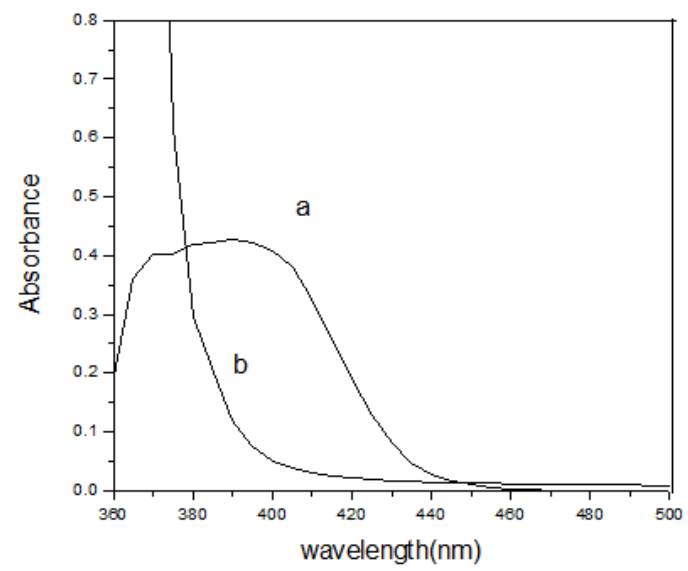

Fig: 1 Absorption spectra of (a) 5-BHMBHBH Vs buffer blank (b) [Al (III)]-5-BHMBHBH Vs reagent bank $[\mathrm{Al}(\mathrm{III})]=1.6 \times 10^{-5} \mathrm{M}: 5-\mathrm{BHMBHBH}=1.0 \times 10^{-2} \mathrm{M} \mathrm{pH}=4.0$ 